\title{
ОСОБЛИВОСТІ РІВНІВ ЗАПАЛЬНИХ МАРКЕРІВ У ХВОРИХ НА ГІПЕРТОНІЧНУ ХВОРОБУ ІІ СТАДІЇ: ФОКУС НА ОРГАНИ-МІШЕНI
}

\author{
к. мед.н. Олександр Гончаров \\ Украӥна, Запоріжжя, Запорізький державний медичний університет, \\ асистент кафедри внутрішніх хвороб 2
}

DOI: https://doi.org/10.31435/rsglobal_ws/28022020/6927

\section{ARTICLE INFO}

Received: 21 December 2019

Accepted: 18 February 2020

Published: 28 February 2020

\section{KEYWORDS}

arterial hypertension, inflammatory activation, C-reactive protein, alpha-tumor necrosis factor, target organs.

\begin{abstract}
Arm of our study was to evaluate the levels of inflammatory markers in patients with arterial hypertension stage II with depending on the numbers of affected target organs. Levels of C-reactive protein and alpha-tumor necrosis factor were significantly higher in patients with arterial hypertension than in healthy individuals. An involvement of more target organs damages was associated with greater inflammatory activation in hypertensive patients. The levels of C-reactive protein and $\alpha$-tumor necrosis factor had significant correlation relationship with the markers of target organ damage.
\end{abstract}

Citation: Олександр Гончаров. (2020) Osoblyvosti Rivniv Zapalnykh Markeriv u Khvorykh na Hipertonichnu Khvorobu II Stadii: Fokus na Orhany-Misheni. World Science. 2(54), Vol.1. doi: 10.31435/rsglobal_ws/28022020/6927

Copyright: (C) 2020 Олександр Гончаров. This is an open-access article distributed under the terms of the Creative Commons Attribution License (CC BY). The use, distribution or reproduction in other forums is permitted, provided the original author(s) or licensor are credited and that the original publication in this journal is cited, in accordance with accepted academic practice. No use, distribution or reproduction is permitted which does not comply with these terms.

Вступ. Згідно даним Всесвітньої організації охорони здоров'я у світі кожен 3-4 дорослий віком старше 25 років страждає на артеріальну гіпертензію (АГ) [1].

Останніми роками важливими маркерами, які визначають прогноз у пацієнтів з АГ, є ознаки ураження органів-мішеней $(\mathrm{OM})[2,3,4]$. Результати багатьох досліджень свідчать про те, що розвиток та прогресування АГ і гіпертензивного ураження ОМ можуть бути обумовлені не лише гемодинамічними чинниками, але й імунними реакціями $[5,6]$. У декількох дослідженнях показано взаємозв'язок між різними запальними молекулами і наявністю ураження органів- мішеней у пацієнтів з гіпертонічною хворобою (ГХ) $[7,8,9]$. Наші роботи також засвідчили, що прозапальна активація відіграє важливу роль у розвитку серцево-судинного ремоделювання при ГХ [10].

Однак, незважаючи на досить велику кількість робіт, до кінця не розкрита динаміка маркерів запалення у залежності від тяжкості уражень органів-мішеней при АГ.

Мета роботи: дослідити рівень С-реактивного протеїну (СРП) та альфа-фактору некрозу пухлини ( $\alpha$-ФНП) у хворих на гіпертонічну хворобу II стадії в залежності від кількості уражених органів-мішеней.

Об'єкт і методи дослідження: у дослідження включено 104 хворих на ГХ ІІ стадії без клінічно значущої супутньої патології. Серед обстежених було 62 жінки і 42 чоловіки віком від 31 до 73 років. Діагноз ГХ був встановлений згідно уніфікованого клінічного протоколу первинної, екстреної та вторинної (спеціалізованої) медичної допомоги й оновленої та адаптованої клінічної настанови, заснованої на доказах, 3 артеріальної гіпертензії (Наказ Міністерства охорони здоров'я України від 24.05.2012 року № 384) [11]. Кожен пацієнт дав добровільну письмову згоду на участь у даному дослідженні.

Для верифікації ураження органів-мішеней (серце, нирки, судини) всім пацієнтам проведено ехокардіографію, дослідження рівня добової мікроальбумінурії та визначення товщини інтимо-медіального сегменту загальних сонних артерій. 
У якості маркера ураження серця використовували показник індексу маси міокарда лівого шлуночка (ІММЛШ), який обчислювався шляхом відношення маси міокарда лівого шлуночка до площі поверхні тіла пацієнта. Маса міокарда розраховувалася за допомогою формули Devereux [12]. Критерієм ураження серця була величина ІММЛШ більше $115 \mathrm{r} / \mathrm{M}^{2}$ для чоловіків і більше $95 \mathrm{r} / \mathrm{M}^{2}$ для жінок. Ехокардіографія виконувалася на ультразвуковому апараті "MyLab 50X" фірми Esaote.

У якості маркера ураження нирок використовували показник добової мікроальбумінурії (ДМАУ). Критерієм пошкодження нирок вважали рівень ДМАУ у межах 30-300 мг/добу. Дослідження рівня мікроальбумінурії проводилося в клініко-діагностичній лабораторії КНП «Міська лікарня №7» Запорізької міської ради.

Як маркер ураження артерій використовували показник товщини інтимо-медіального сегменту (TIMC) загальної сонної артерії більше 0,9 мм. TIMC вимірювали за допомогою лінійного датчика 3 частотою 10 Мгц на 1-2 см нижче біфуркації. Вимірювання ТІМС загальної сонної артерії проводили згідно рекомендацій Tahmasebpour H.R. [13]. Ультразвукове дослідження сонних артерій виконувалося на ультразвуковому апараті «MyLab 50X» фірми Esaote.

Всім пацієнтам визначали рівень СРП та альфа-ФНП в сироватці крові. Рівень СРП визначали за допомогою набору «Microwell ELISA» фірми «Diagnostic Automation, Inc.». Вміст $\alpha$-ФНП в сироватці крові визначали за допомогою набору «Human TNF $\alpha$ ELISA» фірми «Diaclone» Дослідження проводили відповідно до прикладеної до наборів інструкції. Визначення рівня СРП та $\alpha$-ФНП проводили на базі Центральної науково-дослідної лабораторії Запорізького державного медичного університету на фотометрі «Digiscan Microplate Reader».

Для аналізу отриманих результатів використовували методи параметричної i непараметричної статистики із застосуванням програми Excel пакету Microsoft Office 365. Показники наведені у вигляді $\mathrm{M} \pm \mathrm{m}$ (середнє значення \pm похибка середнього), $\mathrm{Me}(25,75 \%)$ (Медіана; 25; 75 перцентиль) та абсолютне значення (відсоток) (n (\%)). Взаємозв'язки параметрів аналізувались із використанням коефіцієнта кореляції Спірмена (r). Вірогідність різниці оцінювали за допомогою t-критерію Стьюдента та U-критерію Манна-Уітні. Різниця вважалась вірогідною при значеннях $\mathrm{p}<0,05$.

Результати дослідження.

У дослідження було включено 104 хворих з ГХ ІІ стадії, серед яких 72 пацієнта $(69,2 \%)$ мали ураження серця, 61 хворий (58,7\%) - ураження нирок і 58 пацієнтів (55,8\%) - судинне ураження.

У залежності від кількості уражених органів-мішеней пацієнти групи спостереження були розподілені на 3 групи. Першу групу склали 25 хворих із ознаками ураження одного органу-мішені. До 2-ї групи увійшли 50 пацієнтів, що мали ознаки ураження двох органівмішеней. Третю групу склали 29 хворих з ознаками ураження трьох органів-мішеней. Групу контролю склали 28 практично здорових об'єктів.

Рівні маркерів прозапальної активації та показники маркерів ураження органів-мішеней у хворих на ГХ, а також у осіб групи контролю, представлені у табл. 1.

Таблиця 1. Характеристика маркерів запалення та ураження органів-мішеней у досліджуваних осіб.

\begin{tabular}{|c|c|c|c|c|c|}
\hline \multirow[b]{2}{*}{ Показник } & \multicolumn{4}{|c|}{ Хворі з ГХ } & \multirow[b]{2}{*}{$\begin{array}{r}\text { Контрольна } \\
\text { група }(\mathrm{n}=28)\end{array}$} \\
\hline & $\begin{array}{c}\text { Всього по групі } \\
(\mathrm{n}=104)\end{array}$ & $\begin{array}{l}1 \text { група } \\
(\mathrm{n}=25)\end{array}$ & $\begin{array}{c}2 \text { група } \\
(\mathrm{n}=50)\end{array}$ & $\begin{array}{c}3 \text { група } \\
(\mathrm{n}=29)\end{array}$ & \\
\hline СРП, мГ/л & $\begin{array}{c}4,14^{*} \\
{[2,12 ; 5,37]}\end{array}$ & $\begin{array}{c}1,54^{*} \\
{[0,95 ; 2,92]}\end{array}$ & $\begin{array}{c}4,02^{* \#} \\
{[1,94 ; 5,03]}\end{array}$ & $\begin{array}{c}5,38^{* \# \S} \\
{[4,89 ; 7,35]}\end{array}$ & $\begin{array}{c}0,84 \\
{[0,52 ; 1,28]}\end{array}$ \\
\hline $\begin{array}{l}\alpha-\Phi Н П, \\
\text { пг/мл }\end{array}$ & $\begin{array}{c}141,80^{*} \\
{[110,43 ; 164,03]}\end{array}$ & $\begin{array}{c}134,40^{*} \\
{[107,10 ; 140,50]}\end{array}$ & $\begin{array}{c}151,70^{* \#} \\
{[132,90 ; 168,38]}\end{array}$ & $\begin{array}{c}164,78^{* \#} \\
{[156,80 ; 189,30]}\end{array}$ & $\begin{array}{c}105,45 \\
{[102,30} \\
110,93]\end{array}$ \\
\hline $\begin{array}{l}\text { IMМЛШ, } \\
\Gamma / \mathrm{M}^{2}\end{array}$ & $106,0 \pm 1,26^{*}$ & $102,56 \pm 2,60^{*}$ & $106,45 \pm 1,95^{* \#}$ & $116,52 \pm 1,94^{* \# \S}$ & $94,86 \pm 2,11$ \\
\hline TIMC, MM & $1,10 \pm 0,02^{*}$ & $0,86 \pm 0,03^{*}$ & $1,01 \pm 0,02^{* \#}$ & $1,21 \pm 0,02^{* \# \S}$ & $0,65 \pm 0,02$ \\
\hline $\begin{array}{l}\text { ДМАУ, } \\
\text { мг/доба }\end{array}$ & $155,0 \pm 9,98^{*}$ & $48,0 \pm 14,06^{*}$ & $95,31 \pm 12,83^{* \#}$ & $215,17 \pm 15,95^{* \# \S}$ & $16,0 \pm 12,14$ \\
\hline
\end{tabular}

Примітка. * - $<<0,05$ у порівнянні з групою контролю, ${ }^{\#}$ - p $<0,05$ у порівнянні 3 пацієнтами 31 групи; $\$$ - $\mathrm{p}<0,05$ у порівнянні 3 пацієнтами $з 2$ групи.

В результаті проведеного дослідження було встановлено, що у цілому по групі хворих на ГХ вміст СРП у сироватці крові був вірогідно вищим у 3,93 рази у порівнянні з особами групи 
контролю. Аналогічна тенденція спостерігалася і відносно рівня $\alpha$-ФНП в сироватці крові. Так його показники у групі хворих на ГХ були вірогідно вищими на 34,47\% у порівнянні з групою контролю.

При вивченні параметрів активації запальних процесів у хворих на ГХ у залежності від кількості уражених ОМ було встановлено, що при зростанні кількості уражених ОМ у пацієнтів відзначається прогресивне підвищення вмісту СРП і $\alpha$-ФНП у сироватці крові. При цьому динаміка змін цих показників була досить вираженою. Так, у хворих 2 групи рівні С-реактивного протеїну й $\alpha$-ФНП були в 1,61 рази $(\mathrm{p}<0,05)$ та на $12,87 \%(\mathrm{p}<0,05)$ відповідно вищими у порівнянні 3 пацієнтами з наявністю ураження одного ОМ. У осіб 3 групи вміст СРП й $\alpha$-фактору некрозу пухлини у сироватці крові відзначався відповідно на 33,83\% (p<0,05) і 8,62\% (p>0,05) більшим, ніж у хворих 2 групи. Найбільш значними виявилися відмінності між досліджуваними показниками між пацієнтами з ураженнями трьох та одного ОМ - вищим у 2,49 разів (p<0,05) для вмісту СРП, а також вищим на 22,02\% ( $<<0,05)$ для $\alpha$-фактору некрозу пухлини.

Аналізуючи взаємозв'язок між СРП і маркерами ураження ОМ було зарєєстровано статистично значущі позитивні кореляційні взаємозв'язки середньої сили між рівнем СРП у сироватці крові та показниками IMМЛШ (r=0,52, p<0,05), TIMC ( $\mathrm{r}=0,57, \mathrm{p}<0,05)$, та позитивний кореляційний взаємозв'язк слабкої сили між СРП у сироватці крові та рівнем ДМАУ ( $\mathrm{r}=0,34$, p $<0,05)$. Подібна спрямованість кореляційних взаємозв'язків також була виявлена між рівнем $\alpha-$ ФНП у сироватці крові та маркерами ураження ОМ: для ТІМС - r=0,62, p<0,05, ІММЛШ $\mathrm{r}=0,47, \mathrm{p}<0,05$ і ДМАУ - r=0,32, $\mathrm{p}>0,05$ відповідно.

Висновки. 1. У хворих на гіпертонічну хворобу рівні С-реактивного протеїну й $\alpha$ фактору некрозу пухлини є достовірно вищими, ніж у практично здорових осіб.

2. У пацієнтів з есенціальною артеріальною гіпертензією збільшення кількості уражених органів-мішеней супроводжується більш високими рівнями маркерів запалення у сироватці крові.

3. При гіпертонічній хворобі рівні С-реактивного протеїну та $\alpha$-фактору некрозу пухлини мають значущі кореляційні взаємозв'язки з маркерами уражень органів мішеней.

\section{ЛІТЕРАТУРА}

1. A global brief on hypertension. World Health Day 2013. World Health Organization 2013. P. 8.

2. Schmieder R E. End Organ Damage In Hypertension. Dtsch. Arztebl. Int. 2010. Vol. 107(49). P. 866-873. DOI: $10.3238 /$ arztebl.2010.0866/

3. C. Cuspidi, G. Macca, I. Michev et al. Left ventricular concentric remodelling and extracardiac target organ damage in essential hypertension. Journal of Human Hypertension. 2002. Vol. 16. P. 385-390. DOI: https://doi.org/10.1038/sj.jhh.1001420

4. Schrader J., Luders S., Kulschewski A., et al. Microalbuminuria and tubular proteinuria as risk predictors of cardiovascular morbidity and mortality in essential hypertension: final results of a prospective long-term study (MARPLE Study). J. Hypertens. 2006. Vol. 24. P. 541-548. DOI: 10.1097/01.hjh.0000209991.48928.c4.

5. Wenzel U., Turner J.E., Krebs C., et al. Immune mechanisms in arterial hypertension. J Am Soc Nephrol. 2016. Vol. 27. P. 677-686. DOI: 10.1681/ASN.2015050562.

6. William G., McMaster, Annet Kirabo, et al. Inflammation, Immunity, and Hypertensive End-Organ Damage. Circ Res. 2015. Vol. 116. P. 1022-1033. DOI: 10.1161/CIRCRESAHA.116.303697.

7. Pedrinelli R., Dell'Omo G., Di Bello V., Pontremoli R., Mariani M. Microalbuminuria, an integrated marker of cardiovascular risk in essential hypertension. J Hum Hypertens. 2002. Vol. 16. P. 79-89. DOI: 10.1038/sj.jhh.1001316.

8. Navarro-Gonzarlez J.F., Mora C., Muros M., Jarque A., et al. Association of tumor necrosis factor-alpha with early target organ damage in newly diagnosed patients with essential hypertension. J Hypertens. 2008. Vol. 26. P. 2168-2175. doi: 10.1097/HJH.0b013e32830e2545

9. D. Muller, H. Kvakan, F. Luft. Immune-related effects in hypertension and target-organ damage. Current Opinion in Nephrology and Hypertension. - 2011. - Vol. 20(2). - P. 113-117. DOI: 10.1097/MNH.0b013e3283436f88.

10. В. А. Візір, О. В. Гончаров, А. С. Садомов. Особливості прозапальної активації та ії роль в патогенезі серцево-судинного ремоделювання у хворих на гіпертонічну хворобу II стадії. Запорожский медичинский журнал. 2013. № 4. C. 5-9. DOI: https://doi.org/10.14739/2310-1210.2013.4.16826

11. "Уніфікований клінічний протокол первинної, екстреної та вторинної (спеціалізованої) медичної допомоги артеріальна гіпертензія". Затверджено Наказ Міністерства Охорони Здоров'я від 24 травня 2012 року № 384. URL: https://www.apteka.ua/article/151151.

12. Devereux R, Alonso D, Lutas E, Gottlieb G, Campo E, Sachs I, Reichek N. Echocardiographic assessment of left ventricular hypertrophy: comparison to necropsy findings. Am J Cardiol. 1986. Vol. 57. P. 450-458. DOI: 10.1016/0002-9149(86)90771-x.

13. Tahmasebpour H.R., BuckleyA.R., Cooperberg P.L. [et al.]. Sonographic Examination of the Carotid Arteries. RadioGraphics. 2005. Vol. 25. P. 1561-1575. DOI: 10.1148/rg.256045013. 